\title{
ANALISIS STRATEGI GURU DALAM MENGEMBANGKAN AKHLAK PADA ANAK USIA DINI
}

\author{
Bujuna Alhadad1, Rita Samad,2, Andriani Hamide ${ }^{3}$ \\ Universitas Khairun \\ Fakultas Keguruan Dan Ilmu Pendidikan \\ Jl.Bandara Sultan Babulla Kota Ternate Utara, Kode Pos 53 Ternate 97728 \\ Telepon (0921)3110905-Faksimili 0921-3110901 \\ Email: bujunaalhadad@gmail.com
}

\begin{abstract}
Abstrak: Strategi penanaman akhlak sangat penting untuk diberikan sedini mungkin. Karena saat usia dini adalah waktu yang tepat untuk memberikan rangsangan yang positif kepada anak. Pendidikan penanaman akhlak pada usia dini menentukan perkembangan akhlak anak selanjutnya. Yang dimaksud dengan pendidikan akhlak adalah pembiasaan seorang anak untuk berakhlak baik, termaksud dalam pendidikan akhlak adalah menjauhkan anak dari akhlak yang tercela dan perangai buruk. Seorang anak akan tumbuh sesuai dengan kebiasaan yang di tanamkan oleh sang pendidik terhadapnya. Oleh karena itu dalam pemilihan strategi pembelajaran dalam mengembangkan akhlak pada anak, guru harus mampu memilih strategi pembelajaran yang baik agar anak mampu memahami apa yang di sampaikan pendidik tentang penanaman akhlak. Strategi penanaman akhlak diantaranya strategi pendidikan langsung dan pendidikan tidak langsung, Pendidikan langsung diantaranya keteladanan, anjuran, dan latihan, serta pendidikan tidak langsung diantaranya adalah, larangan, hukuman, hadia, dan pengawasan. Ada berbagai macam gambaran yang telah dijelaskan dalam Al-Quran mengenai pendidikan akhlak untuk anak usia dini yang tertuang dalam surat Lukman diantaranya akhlak pada Allah SWT, akhlak kepada orang tua, akhlak kepada orang lain dan akhlak terhadap diri sendiri. Metode yang digunakan dalam penelitian ini dengan pendekatan studi literature (library reseach). Dari hasil penelitian dapat di simpulkan bahwa strategi guru sangat berperan penting dalam mengembangkan akhlak anak.

Kata Kunci: Strategi Guru, Akhlak, Anak
\end{abstract}

\begin{abstract}
A moral cultivation strategy is very important to be given as early as possible. Because at an early age is the right time to provide positive stimulation to children. Moral cultivation education at an early age determines the subsequent moral development of the child. What is meant by moral education is the habituation of a child to have good character, what is meant in moral education is to keep the child away from disgraceful morals and bad character. A child will grow by the habits instilled by the educator towards him. Therefore, in choosing a learning strategy in developing morals in children, the teacher must be able to choose a good learning strategy so that the child can understand what the teacher says about moral cultivation. The strategy of cultivating morals includes direct and indirect education strategies, direct education including exemplary, encouragement and training, and indirect education including prohibition, punishment, hadia, and supervision. There are various kinds of descriptions that have been described in the Al-Quran regarding moral education for early childhood which is contained in the Lukman letter including morals to Allah SWT, morals to parents, morals to others, and morals towards oneself. The method used in this research is a literature study approach (library research). From the research results, it can be concluded that teacher learning strategies play an important role in developing early childhood morals.
\end{abstract}

Keywords: Teacher's Strategy, Children's Morals 


\section{A. Pendahuluan}

Dalam Undang-undang RI Nomor 20 Tahun 2003 pada Pasal 1 tentang Sistem Pendidikan Nasional disebutkan bahwa PAUD adalah suatu upaya pembinaan yang ditujukan kepada anak-anak sejak lahir hingga usia enam tahun yang dilakukan melalui pemberian rangsangan pendidikan untuk membantu pertumbuhan dan perkembangan jasmani serta ruhaninya agar anak memiliki kesiapan dalam memasuki jenjang pendidikan lebih lanjut.

Pendidikan Anak Usia Dini juga bertujuan untuk mewujudkan suasana belajar yang aktif dan kondusif agar dapat mengembangan daya berfikir anak lebih leluasa dan mengajarkan anak untuk lebih bersikap lebih baik sesama orang lain, dan menjadikan pribadi anak lebih baik. Jadi pendidikan anak usia dini sangat penting dilaksanakana karena anak yang berusia 0-6 tahun berada pada masa keemasan yang mana pada masa ini guru dan orang tua dapat mengembangakan seluruh potensi anak secara optimal baik dalam aspek moral dan agama, sosial emosional, fisik motorik, kognitif, serta bahasa. Keberhasilan anak di PAUD merupakan cerminan untuk melihat keberhasilan anak di masa mendatang. Anak yang mendapatkan layanan yang baik sejak dini memiliki harapan lebih besar untuk meraih kesuksesan di masa kedepannya.

Ki Hadjar Dewantara (3013: 13) berpendapat bahwa pendidikan anak usia dini adalah pendidikan dimana anak belum belajar menggunakan fikirannya, melainkan anak belajar dalam masa pertumbuhannya. Anak usia dini dapat berupa permainan, nyanyian, bercerita, bekerja secara bermain-main, serta memelihara tanaman, bunga, dan sayuran.

Hibana S. Rahman (2002: 15) berpendapat bahwa tujuan pendidikan anak usia dini secara umum dapat diartikan untuk menfasilitasi pertumbuhan dan perkembangan anak secara optimal dan menyeluruh sesuai dengan normanorma dan nilai kehidupan yang dianut.

Guru juga merupakan titik sentra pendidikan, pengajar maupun pengabdian guru ada pada peserta didik. Peran ini mendorong guru untuk tau banyak tentang kondisi peserta didik di tiap jenjang. Selain itu, kesuksesan guru di tentukan pula oleh penguasaan materi, cara menggunakan pendekatan dan strategi yang tepat dan serta dukungan sumber, alat dan media pembelajaran yang cukup.

Seorang pendidik dituntut untuk mau dan mampu mendidik peserta didik agar menjadi anak yang berakhlak mulia, dan mampu mengubah akhlak buruk menjdi akhlak yang baik. Praktek etika atau budi pekerti tidak akan cukup hanya diberikan sebagai pelajaran yang konsekuensinya hafalan atau lulus dari ujian tulisan. Perilaku keseharian anak didik khususnya di sekolah akan terkait erat dengan lingkungan yang ada. Sangat eronis bahkan menjadi mustahil terwujud jika anak dituntut untuk berperilaku terpuji, sementara kehidupan di sekolah terlalu banyak elemen yang tercela.

Perbaikan akhlak merupakan suatu misi yang paling utama yang harus dilakukan oleh pendidik kepada anak didiknya. Strategi merupakan komponen yang sangat berpengaruh dalam dunia pendidikan, terlebih terkait dengan proses pembinaan akhlak. Pendidikan akhlak berusaha menciptakan situasi dan kondisi sedemikian rupa, sehingga peserta didik terdorong dan tergerak jiwa dan hatinya untuk berperilaku dan beradab, atau sopan santun yang baik sesuai dengan harapan lembaga pendidikan. Mengingat dierah yang serba canggi sekarang banyak anak-anak menggunakan gedjek dalam hal yang tidak baik, 
seperti menonton film yang terdapat adegan kekerasan sehingga anak dapat meniru hal tersebut.

Maka dari itu seorang guru harus memili berbagai macam strategi untuk meningkatkan akhlak pada anak, di antaranya dengan menggunakan strategi (1) strategi pendidikan langsung diantranya keteladanan, anjuran, latihan dan (2) pendidikan tidak langsung diantaranya adalah larangan, hukuman, hadia, dan pengawasan. Yang dimana strategi merupakan pendekatan secara keseluruhan yang berkaitan dengan pelaksanaan gagasan, perencanaan, dan eksekusi sebuah aktivitas dalam kurun waktu tertentu. Dalam mengembangkan akhlak pada anak harus harus sesuai dengan yang sudah di cantumkan dalam Al-quran yang terdapat dalam surah lukman yang di antaranya (1) akhlak pada Allah SWT, (2) akhlak kepada orang tua, (3) akhlak kepada orang lain dan (4) akhlak terhadap diri sendiri. Tantangan yang dihadapi oleh para penggerak dunia pendidikan saat ini semakin banyak, salah satunya adalah perubahan atmosfer dunia pendidikan yang sebagian besar dipengaruhi oleh adanya perkembangan teknologi yang akan terjadi.

Selain memberi dampak yang baik bagi peningkatan kualitas pembelajaran ternyata perkembangan teknologi ini juga memberikan efek samping yang kurang baik bagi dunia pendidikan terutama jika menyangkut tentang penyalahgunaan yang terjadi di lingkungan peserta didik. Karenanya dalam menyampaikan pelajaran dan menjawab tantangan perkembangan teknologi yang terjadi, seorang tenaga pendidik haruslah aktif dalam mengikuti perkembangan tersebut dan memikirkan strategi pembelajaran yang baik untuk peserta didik yang diilikinya. Dalam mendidik akhlak perlu sebuah sistem yang tepat agar proses internalisasi dapat berjalan dengan baik, lebih penting adalah peserta didik mampu menerima konsep akhlak dengan baik serta mampu mewujudkan dalam kehidupan keseharian.

\section{B. Pembahasan}

\section{Strategi Guru}

Strategi menurut kamus besar Bahasa Indonesia adalah rencana yang cermat mengenai kegiatan untuk mencapai sasaran khusus. Sedangkan menurut Abuddin Natta, strategi pada intinya adalah langkah-langkah terencana yang bermakna luas dan mendalam yang dihasilkan dari sebuah proses pemikiran dan perenungan yang mendalam berdasarkan pada teori dan pengalaman. Dalam dunia pendidikan, strategi diartikan sebagai perencanaan yang berisi tentang rangkaian kegiatan yang didesain untuk mencapai tujuan pendidikan tertentu. (Junaedin, 2018: 11).

Strategi juga merupakan penggambungan berbagai macam tindakan untuk mencapai tujuan kegiatan. Pada TK kegiatan dapat dilakukan dalam bentuk bermain dan kegiatan yang lain. Dan kegiatan strategi lebih banyak menekankan pada aktivitas anak dari pada aktivitas guru. Di samping itu strategi pembelajaran anak usia dini harus dilakukan dengan menarik, mensosial, penuh dengan permainan dan keceriaan serta tidak merampas dunia kanak-kanak mereka. Dan dalam strategi pembelajaran kita perlu mengembangkan dan memperhatikan pendekatan pembelajaran yang menjadikan mereka senang, asyik, kreatif dan aktif, sehingga lepas dari suasana tertekan, dan tidak terbebani. (Nurmaidah 2015: 12).

Dalam proses belajar di sekolah guru merupakan sumber daya edukatif yang utama dalam menentukan mutu pembelajaran tersebut. 
Mengajar bukanlah suatu pekerjaan yang mudah bagi guru, akan tetapi diperlukan kemampuan dan pemahaman yang sangat besar untuk mampu mengajar dengan baik. "Mengajar pada dasarnya merupakan suatu usaha untuk menciptakan kondisi atau sistem lingkungan yang mendukung dan memungkinkan untuk berlangsungnya proses belajar". (Sardiman 2006: 1315).

Menurut Gulo (2002: 14) mendefenisikan. Strategi guru mengajar adalah suatu seni dan ilmu guru untuk membawakan pengajaran di kelas sedemikian rupa sehingga tujuan yang telah ditetapkan dapat di capai secara efektif dan efisien. Sedangkan Wena (2009: 14), mendefinisikan. Strategi guru mengajar sebagai cara dan seni guru untuk menggunakan semua sumber belajar dalam upaya pembelajaran siswa.

Strategi yang harus dilakukan guru dalam mengembangkan akhlak pada anak adalah, guru harus mengenal anak didiknya terlebih dahulu, lalu mencoba mendapati hal-hal positif yang ada pada mereka dan secara terus terang menyatakan suatu penghargaan, selain itu juga ia harus mengetahui kondisi keluarga masing-masing anak didik, kesulitan yang mereka hadapi dan kebutuhan yang mereka perlukan.

Dengan demikian materi pendidikan agama yang terpenting diberikan untuk anak didik dalam upaya pembinaan akhlak anak didik adalah pembinaan akhlakul karimah, pembinaan ini dilakukan dengan pemberian materi tentang berbagai macam kehidupan anak didik misalnya mengenai tata karma, sopan santun, cara bergaul, cara berpakaian, dan cara bermain yang tidak bertentangan dengan ajaran Islam, di samping itu juga pelaksanaan ibadah yang sesuai dengan syariat ajaran Islam, terutama tentang aqidah atau ketauhidan kepada Allah. (dalam Affan 2004: 55)

Menurut Zuhairini, (2004: 20) tugas guru agama dalam mengembangkan akhlak antara lain: 1). Mengajarkan ilmu pengetahuan agama Islam, 2). Menanamkan keimanan dalam jiwa anak, 3). Mendidik anak agar taat dalam menjalankan ibadah, 4). Mendidik anak agar berbudi pekerti yang mulia.

Berkaitan dengan pendidikan Islam, yaitu pembentukan akhlak dan budi pekerti yang mampu menghasilkan orang-orang yang bermanfaat, jiwa yang bersih, mempunyai cita-cita yang luhur, berakhlak mulia, mengerti tentang kewajiban dan pelaksanaanya, dapat menghormati orang lain terutama kepada orang tua, mampu membedakan mana yang baik dan mana yang buruk.

Langkah-langkah yang harus dilakukan guru dalam mengembangkan akhlak anak menurut pendidikan agama Islam antara lain:

a. Memberikan panutan atau teladan sebelum akhirnya lanjut ke tahap pembelajaran berikutnya kepada peserta didik, seperti shlat dzuhur berjama'ah, mengaji al-Qur'an, sopan terhadap semua orang, dan memberikan contoh bagaimana cara bertutur kata yang baik. hal tersebut harus dilakukan guru karena seorang guru merupakan contoh terbaik bagi peserta didiknya. (Maulizar, 2017: 23).

b. Diakhir shlat dzuhur berjama'ah peserta didik dibiasakan duntuk berdo'a bersama lebih dahulu. Kegiatan ini dilaksanakan agar peserta didikm menjadi orang yang disiplin dan bertaqwa kepada Allah. Bagi peserta didik yang tidak melaksanakan shlat dzuhur berjama'a, guru 
pendidikan agama Islam akan memberikan peringatan maupun hukuman yang mendidik. Seperti menulis istiqfar 100 kali dan dikumpulkan. Hal tersebut digunakan untuk memberikan penyesalan kepada peserta didik agar tidak melakukan keselahan lagi. (Mila Intani, 2017: 25).

c. Peserta didik dibiasakan untuk membaca al-Qur'an bersama sebelum prose belajar-mengajar. Di dalam kegiatan proses pembelajaran guru juga harus menjadi teladan atau panutan bagi peserta didik baik dari sikap maupun tutur kata seperti cara berpakaian dan berias yang dianjurkan oleh ajaran Islam, bertutur kata yang lemah lembut, dan berperilaku yang sopan. Diakhir pembelajaran guru juga membiasakan peserta didik berdo'a bersama untuk mengakhiri pembelajaran.

Dari beberapa teori di atas dapat disimpulkan. Strategi merupakan prosedur yang dilakukan pendidik dalam melaksanakan pembelajaran, dalam hal ini untuk mencapai suatu pembelajaran yang efektif dalam kelas.

Penanaman nilai-nilai agama Islam pada anak usia dini penting sekali untuk dilakukan. Anak usia dini berada pada tahap the fairy tale stage dalam perkembangan agamanya. Anak pada tahap tersebut masih menggunakan fantasi dan emosi dalam memahami konsep keagamaan. Hal ini sesuai dengan perkembangan intelaktualnya. Oleh karena itu seorang guru diperlukan latihan dan bimbingan dalam mengembangkan nilai-nilai agama agar anak mempunyai kepribadian baik.

Strategi pendidikan guru agama Islam mengandung pengertian rangkaian perilaku pendidikan yang tersusun secara terencana dan sistematis untuk menginformasikan, mentransformasi, dan menginternalisasikan nilai-nilai islam, dengan adanya strategi ini menjadikan anak lebih terarah sehingga dapat membentuk kepribadian muslim seutuhnya. Misalnya membiasakan anak saat masuk di dalam lingkungan sekolah mencium tangan ibu guru, membuang sampah pada tempatnya, melakukan baris berbaris sebelum masuk di dalam kelas, namun di dalam berbaris tersebut guru hrus menyampaikan arahan kepada anakanak apa yang harus di lakukan saat masuk di dalam kelas, dan pada saat memulai pembelajaran anak di haruskan membaca doa belajar, doa kedua orang tua, doa selamat dunia akhirat, dan hafalan surah-surah pendek.

Strategi yang dapat dilakukan dalam upaya pendidikan atau pembinaan akhlak anak terdapat beberapa strategi yang digunakan diantaranya adalah:

a. Pendidikan Secara Langsung

Pendidikan secara langsung yaitu dengan mengadakan hubungan langsung secara pribadi maupun secara kekeluargaan antara orang tua dan anak, ketika dalam lingkungan keluarga atau guru dengan murid, ketika dalam lingkungan sekolah. Caranya dengan mempergunakan petunjuk, nasihat, tuntunan dan lain sebagainya.

Strategi guru yang dilakukan dalam pendidikan secara langsung untuk mengembangkan akhlak anak yaitu, guru menyampaikan hal-hal yang berhubungan dengan akhlak anak di sampaikan secara bertatapan langsung dengan anak, yaitu dengan cara mempergunakan petunjuk, tuntutan, nasehat, menyebutkan manfaat dan bahaya-bahaya. Anak dijelaskan hal-hal yang bermanfaat dan yang tidak bermanfaat, 
menuntut kepada amal-amal yang baik, yang mendorong mereka berbudi pekerti yang tinggi, dan menghindari hal-hal tercela. Untuk pendidikan cara ini guru dapat menggunakan sajak-sajak, syair-syair, motto, pepatah, dan lain sebagainya. Contohnya adalah, budi pekerti yang baik adalah teman yang sejati, atau tidak ada bencana yang lebih besar dari kejahilan. Pendidikan ini dapat juga digunakan dengan menggunakan ayat-ayat al-quran dan al-hadits, yang disampaikan unsurunsur akhlaknya. Menurut Marimba, pendidikan secara langsung terdapat tiga macam yaitu:

1) Teladan

Keteladanan dalam pendidikan merupakan bagian dari sejumlah metode yang paling ampuh dan efektif dalam mempersiapkan dan membentuk anak secara moral, spiritual, dan sosial. Sebab, seorang pendidik merupakan contoh ideal dalam pandangan anak, yang tingkah laku dan sopan santunnya akan ditiru, disadari atau tidak, bahkan semua keteladanan itu akan melekat pada diri dan perasaannya, baik dalam bentuk ucapan, perbuatan, hal yang bersifat material, inderawi, maupun spiritual.

Memberi teladan yang baik dalam pandangan Islam merupakan metode pendidikan yang paling membekas pada anak didik. Ketika si anak menemukan pada diri pendidiknya suatu teladan yang baik dalam segala hal, maka ia telah meneguk prinsipprinsip kebaikan yang dalam jiwanya akan membekas berbagai etika Islam.

Contoh strategi yang dapat digunakan guru dalam pendidikan Islam untuk mengembangkan akhlak anak yaitu, selain harus diberikan keteladanan yang tepat, harus juga ditunjukkan bagaimana harus menghormati orang lain, bebicara sopan terhadap yang lebig tua dan seterusnya. Misalnya anak makan bersama, sebelum makan cuci tangan dahulu, tidak boleh makan sebelum baca do'a. anak juga dibiasakan untuk berbagi makanan kepada temannya yang tidak membawa makanan. Dan membiasakan anak untuk mematuhi aturan yang telah di terapkan dalam sekolah. Hal ini dikarenakan agar anak memiliki sikap tanggung jawab pada dirinya, memiliki jiwa kepemimpinan, dan jiwa keikhlasan yang besar dalam menaati aturan yang telah di tetapkan dalam sekolah misalnya: 1) Datang ke sekolah tepat pada waktunya. 2) Mencium tangan ibu dan bapak guru sebelum masuk dalam kelas 3) buang sampah pada tempatnya. 4) Mengerjakan tugas yang sudah di berikan guru.

2) Anjuran

Anjuran yaitu saran atau ajakan untuk berbuat atau melakukan sesuatu yang baik dan berguna, dengan adanya anjuran kedisplinan, melaksanakan kewajiban perintah agama pada anak, sehingga akhirnya menjalankan segala sesuatu dengan disiplin yang nantinya akan membentuk suatu kepribadian yang mulia. Seperti dalam sabda Rasulullah bahwa seorang anak ketika umur 7 tahun atau mungkin di bawahnya harus di ajak untuk melaksanakan shalat lima waktu. Anak-anak hendaklah diajak untuk mengerjakan shalat. 
Sehingga terbentuk manusia yang senantiasa kontak dengan penciptanya.

Strategi anjuran yang di gunakan guru dalam mengembangkan akhlak anak dalam pandangan islam yaitu, dengan membiasakan anak dengan hal-hal yang baik yaitu, anak di biasakan pada saat datang disekolah anak harus melakukan shlah duha terlebih dahulu sebelum memulai pembelajaran, agar anak tumbuh menjadi insan yang benar-benar takwa, yakni insan yang taat melaksanakan segala perintah agama dan taat pula dalam menjauhi segala laranganya, menceritakan kisah-kisah Nabi, menyebutkan jumlah rukun islam dan rukun iman. Hal ini dikarenakan agar anak lebih dekat dengan sang pencitpa.

3) Latihan

Strategi latihan sangat penting di lakukan oleh pendidik pada anak didiknya, karna di dalam proses belajar siswa membutuhkan sebuah latihan dalam sebuah pembelajaran. Tujuan dari latihan adalah untuk menguasai gerakan-gerakan dan menghafalkan ucapan-ucapan. Orang tua ataupun guru harus selalu mengajari atau melatih anak untuk bertutur kata yang sopan.

Penggunaan strategi latihan dapat menggugah akhlak yang baik pada jiwa anak didik sehingga ia tumbuh menjadi pribadi yang lebih iqtiqamah dan bahagia, karena merasakan dirinya sukses dalam perbuatan dan pekerjaannya. Hal ini selanjutnya dapat melahirkan masyarakat yang terpadu.

Dalam menerapkan strategi latihan yang di lakukan guru di sekolah untuk mengembangkan akhlak anak. Guru harus mampu menanamkan aqidah yang baik pada diri anak agar setiap perkembangan dan pertumbuhannya senantiasa dilandasi oleh aqidah yang benar. Dimana membiasakan anak mengucapkan katakata yang mengangungkan Allah, tasbih, istigfar, sholawat dan do'ado'a pendek. Anak dilatih kembali untuk mengulangi kata-kata pendek tersebut seperti asma Allah, tasbih, tahmid, basmalah

b. Pendidikan Secara tidak Langsung

Pendidikan secara tidak langsung, yaitu dengan jalan sugesti, seperti mendiktekan sajak-sajak, kata-kata yang mengandung hikmah, wasiat tentang budi pekerti, anekdot, atau cerita-cerita. Pendidikan juga dapat menyusgetikan kepada anak-anak beberapa contoh dari akhlak yang mulia, seperti berkata benar, jujur dalam pekerjaan, adil dalam menimbang, suka terus terang, berani dan ikhlas.

Pendidikan secara tidak langsung juga merupakan strategi pendidikan yang bersifat larangan atau pencegahan, penekanan. Strategi ini ada empat macam, diantaranya adalah:

1) Larangan

larangan ini merupakan suatu keharusan untuk tidak melakukan perbuatan yang bisa merugikan diri sendiri ataupun orang lain. Usaha ini merupakan tindakan tegas untuk menghentikan perbuatan-perbuatan yang sangat jelas kesalahannya. Larangan ini merupakan suatu perbuatan yang tidak pantas untuk dilakukan seperti mencuri, berkelahi dengan temannya, dan lain sebagainya. 
Perbuatan seperti ini harus dilarang sejak anak masih usia dini, agar ketika sudah dewasa nanti melakukan perbuatan yang dilarang oleh agama merupakan suatu pantangan bagi dirinya. Strategi ini bertuajuan untuk membentuk kedisliplinan atau perbuatan baik bagi anak.

Larangan itu biasanya dikeluarkan jika anak melakukan sesuatu yang tidak baik, yang mungkin dapat membahayakan dirinya. Larangan sebenarnya sama saja seperti perintah. Kalau perintah merupakan suatu keaharusan untuk berbuat sesuatu yang bermanfaat, maka larangan merupakan keharusan untuk tidak melakukan sesuatu yang merugikan (Nurmadiah 2016: 56).

Contoh strategi larangan yang di terapkan oleh guru di dalam sekolah adalah: 1. Mencontek, 2. Berbohong pada guru, 3. Meminta paksa uang teman yang bukan milik kita, 4. Mencuri, 5. Tawuran, 6. Berkata kotor kepada guru. Larangan ini di terapkan agar anak dapat mematuhi aturan tersebut, hingga memiliki akhlak yang lebih baik di masa yang akan datang.

2) Hukuman

Strategi hukuman ini merupakan suatu tindakan yang diberikan kepada anak yang secara sadar dan sengaja melakukan suatu kesalahan, sehinggan dengan adanya hukuman ini anak muncul rasa penyesalan dan tidak melakukan kesalahan untuk yang kedua kalinya. Hukuman ini menghasilkan suatu kedisplinan pada anak. Pada taraf yang lebih tinggi menginsafkan anak untuk tidak melakukan suatu perbuatan yang dilarang oleh agama. Berbuat atau tidak berbuat bukan karna takut hukuman, melainkan karena keinsyafan sendiri dan merupakan suatu ketaatan pada Allah dan selalu mengharapkan ridha-Nya.

Dalam proses pembentukan akhlak, terkadang diperlukan ancaman agar anak tidak bersifat sembrono. Dengan demikian, anak akan enggan ketika akan melanggar norma tertentu. Terlebih jika sangsi tersebut cukup berat. Pendidik atau orang tua terkadang juga perlu memaksa dalam hal kebaikan. Sebab terpaksa berbuat baik itu lebih baik, dari pada berbuat maksiat dengan penuh kesadaran. Jika penanaman nilai-nilai akhlak mulia telah dibiasakan dalam kehidupan sehari-hari, kebiasaan tersebut akan menjadi sesuatu yang ringan. Dengan demikian, ajaran-ajaran akhlak mulia diamalkan dengan baik oleh umat islam.

Seorang guru memberikan hukuman kepada anak karena ada pelanggaran yang dilakukan oleh anak tersebut, misal anak memukul teman, mengambil barang temannya yang bukan miliknya, mengeluarkan kata kata kasar, melanggar aturan yang telah di terapkan disekolah. Jadi dalam pemberian hukuman ini harus disesuaikan dengan kesalahan anak tersebut, namun pemberian hukuman ini tidak harus dengan kekerasan/memukul, tapi guru harus memilih strategi hukuman yang diberikan pada anak harus lebih mengarah pada pengembangan akhlak anak, diantaranya dengan cara menasehati anak tentang apa yang ia lakukan merupakan perbuatan yang tercelah dan tidak di sukai oleh Allah, 
menyuruh anak menghafal ayat-ayat pendek, menyebutkan rukun islam dan rukun iman, menyebutkan nama-nama malaikat.

Dengan demikian dipahami bahwa hukuman diberikan karena ada pelanggaran sedangkan tujuan pemberian hukuman adalah agar tidak terjadi pelanggaran secara berulang. Di dalam bidang pendidikan, hukuman itu dilaksanakan karena dua hal, yaitu: a) Hukuman diadakan karena ada pelanggaran, adanya kesalahan yang diperbuat (punitur, quina peccatum est), b) Hukuman diadakan dengan tujuan agar tidak terjadi pelanggaran (punitur, nepeccatur)

3) Hadiah

Metode hadia dapat diartikan sebagai suatu metode pendidikan yang bertujuan untuk memperbaiki akhlak peserta didik kearah yang lebih baik dan juga memperbaiki akhlak atau perilaku yang tepat dengan cara memberkan hadia yang menyenangkan baik materi ataupun non materi

Pemberian hadia yang diberikan guru kepada anak tidak selalu berupa materi atau barang tetapi pemberian hadia itu juga bisan anggukan dengan wajah yang berserih-serih, ancungan jempol dan lain sebagainya, itu semua sudah termaksud hadiah yang mempunyai pengaruh sangat besar kepada peserta didik, karena dengan adanya hadiah tersebut bisa menggembirakan anak, menambah kepercayaan pada diri sendiri dan yang lebih penting lagi menjadi lebih semangat lagi dalam belajarnya. Misalnya anak disuruh untuk menghafalkan ayat-ayat pendek, mampu menyelesaikan tugas yang di berikan oleh guru, jika anak bisa melakukan hal tersebut maka guru memberikan hadiah dengan tepukan tangan, pelukan atau dengan ucapan anak pintar.

4) Pengawasan

Strategi ini digunakan untuk menjaga agar tidak terjadi halhal yang tidak diinginkan. Karena manusia tidaklah sempurna, jadi kemungkinan besar setelah melakukan kesalahan-kesalahan, penyimpangan-penyimpangan ini selalu ada maka dari itu, sebelum kesalahan dan penyimpangan itu dilakukan lebih jauh sebaiknya selalu ada usaha untuk diadakan pengawasan. Apalagi zaman sekarang anak-anak sudah pandai memainkan gadget, dalam hal ini guru harus bisa benar-benar mengawasi, karena kalu tidak diawasi nanti anak-anak bisa membuka situs-situs yang terlarang yang semua itu merusak moral dan akhlak anak.

Maka dari itu guru harus mampu melakukan pengawasan dengan tepat, baik itu dari jarak jauh maupun dekat, hal ini dikarenakan agar anak-anak didik tidak membuat hal-hal yang tidak di inginkan di dalam lingkungan sekolah. Apalagi di masa usia ini anak lebih cenderung melakukan perbuatan tidak baik. Contohnya memukul/mendorong teman dari luncuran, mengambil barang teman, bertutur kata yang tidak sopan, menggangu teman yang sedang belajar dan menyimpan barang teman. Maka dari itu pengawasan sangat penting di lakukan baik anak saat belajar maupun bermain.

Dari beberapa penjelasan tentang strategi pembelajaran diatas dapat di simpulkan bahwa. Dalam meningkatkan pendidikan 


\section{Akhlak Anak}

akhlak pada anak usia dini guru berhak memiliki strategi pembelajaran yang akan digunakan dalam proses pembelajaran di kelas untuk mencapai suatu pembelajaran yang meningkatkan akhlak pada anak. Yang tepatnya itu dengan menggunakan strategi pendidikan langsung dan strategi pendidikan tidak langsung yang dimana strategi ini tepat untuk digunakan dalam mengembangkan akhlak pada anak usia dini yang telah di tetapkan dalam ajaran agama Islam.

Akhlak menurut bahasa artinya "budi pekerti", adat kebiasaan, perangai, muru'ah, atau segala sesuatu yang menjadi tabi'at. Menurut Abdul Mukmin Sa'adudin (2016: 60), akhlak berasal dari bahasa Arab yang merupakan bentuk jamak dari khuluk yang mengandung arti diantarnya: 1) Tabi'at, yaitu sifat dalam diri yang terbentuk oleh manusia tanpa dikehendaki dan diupayakan, 2) Adat, yaitu sifat dalam diri yang diupayakan manusia melalui latihan yakni berdasarkan keinginannya. 3) Watak, yaitu cukupnya meliputi hal-hal yang menjadi tabi'at dan hal-hal yang diupayakan hingga menjadi adat, kata akhlak juga bisa berarti kesopanan dalam agama.

Pendidikan akhlak dalah salah satu pendidikan yang di wajib diberiakan kepada anak dari sejak usia dini. Hal ini di karenakan pada usia tersebut anak masih suci dan bersih dan belum terkontaminasi dengan berbagai perangai buruk. Oleh karena itu sebagai pendidik dan orang tau perlu mengajarkan dan mencontohkan perbuatan-perbuatan yang mulia yang sesuai dengan ajaran Al-Quran dan hadits Nabi Muhammad SAW.

Menurut Muslich (2011: 212). Menyatakan bahwa seorang anak yang mendapatkan pendidikan akhlak yang baik mampu menghadapai dan menghindari pengaruh buruk dari lingkungan sekitar.

Menurut Mansur Ali Rajab berpendapat bahwa akhlak adalah insting yang di bawah sejak lahir (Bastoni 2017: 98). Akhlak diartikan sebagai pembawaan dari manusia sendiri, yaitu kecenderungan kepada kebaikan atau fitra yang ada dalam hiri manusia dan dapat juga berupa kata hati atau intuisi yang selalu cenderung kepada kebenaran. Dengan pandanganpandangan seperti ini, maka akhlak akan tumbuh dengan sendirinya, walaupun tanpa dibentuk atau diusahakan. Meskipun demikian, diungkapkan pendapat yang tidak setujuh bahwa akhlak merupakan hasil dari pembinaan dan pada kenyataan banyak usaha-usaha pembinaan akhlak melalui berbagai metode yang kemudia di kembangkan.

Hal ini menunjukan bahwa akhlak memang perlu dibina yang mana pembinaan ini akan membawakan hasil berupa terbentuknya pribadipribadi muslim yang berakhlak mulia, taat kepada Allah dan Rasul-Nya, hormat kepada ibu bapak, sayang kepada sesama makhluk Tuhan dan sebagainya (Abuddin 2003: 155). Menjelaskan bahwa anak-anak yang tida dibina akhlaknya dan dibiarkan tanpa bimbingan, arahan dan pendidikan menjadi anak-anak yang nakal seperti menggangu masyarakat, melakukan perbuatan yang tercelah serta tidak memiliki sopan santun. Maka jelas dalam hal ini akhlak memang perlu dibina.

Menurut Mohd. Athiyah al-Abrasyi pendidikan budi pekerti adalah jiwa dari pendidikan Islam, dan Islam telah menyimpulkan bahwa pendidikan budi pekerti dan akhlak adalah jiwa pendidikan Islam. Mencapai 
suatu akhlak yang sempurna adalah tujuan yang sebenarnya dari pendidikan. Pendidikan islam merupakan sarana yang mengantarkan anak didik agar menjadi orang berakhlak. Anak yang memperoleh pendidikan akhlak yang baik tidak hanya merasakan kebaikan di dunia saja tetapi juga sebagai penyelamat dirinya di akhirat nanti. Dengan demikian pendidikan akhlak merupakan kegiatan yang tidak boleh di tunda karena berhubungan dengan seluruh dimensi kehidupan manusia. Kegiatan ini memerlukan keseriusan dan kerja sama seluruh elemen dan pakar pendidikan akhlak. (Herawati, 2017: 129)

Menurut Al-Ghazali sebagai mana yang dikutip oleh Hasan Asari (2012: 150) bahwa akhlak adalah keadaan jiwa yang mantap dan bisa dilahirkan tindakan dengan mudah, tanpa membutuhkan pemikiran dan perenungan. Jika tingkah laku yang lahir dari keadaan jiwa tersebut adalah baik menurut ukuran akal agama, maka keadaan tersebut disebut akhlak baik. Bila tingkah laku yang dihasilkan adalah buruk maka keadaan sumbernya di sebut akhlak buruk. Difenisi Al-Ghazali ini dengan tegas mengatakan bahwa akhlak adalah keadaan jiwa secara internal, sementara tingkah laku adalah indikator eksternal.

Dari beberapa teori di atas dapat di simpulkan bahwa pendidikan akhlak sangat penting di terapkan pada anak usia dini yang dimana karna pada usia ini anak masih memiliki jiwa yang bersih ibaratkan kertas putih tanpa coretan.

Al-Quran telah memberikan gambaran yang jelas mengenai pendidikan akhlak pada anak-anak yang tertuang dalam surat Luqman yaitu:

a. Akhlak Kepada Allah SWT

Akhlak yang baik kepada Allah berucap dan bertingka laku yang terpuji terhadap Allah SWT, baik melalui ibadah langsung kepada Allah, seperti shalat, puasa dan sebagainya, mampu melalui perilaku-perilaku tertentu yang mencerminkan hubungan atau komunikasi dengan Allah di luar ibadah itu. (Habibah, 2015: 78).

b. Akhlak Kepada Orang Tua

Sebagai seorang anak, wajib berbakti kepada orang tua, setela takwa kepada Allah. Orang tua telah berusaha payah memelihara, mengasuh, mendidik sehingga menjadi seorang yang berguna dan bahagia. Karena itu anak wajib menghormatinya, menjunjung tinggi titahnya, mencintai mereka dengan ikhlas, berbuat baik kepadamereka, lebih-lebih bila usia mereka telah lanjut. Jangan berkata keras dan kasar di hadapan mereka. (Asmaran, 2002: 4)

Islam mendidik anak-anak untuk selalu berbuat baik terhadap orang tua sebagai rasa terima kasih atas perhatian, kasih sayang dan semua yang telah mereka lakukan untuk anak-anaknya. Al-Ghazali menegaskan bahwa seorang anak haruslah dididik untuk selalu taat kepada kedua orang tuanya, gurunya serta yang bertanggung jawab atas pendidikannya. Hendaklah menghormati mereka serta siapa saja yang lebih tua daripadanya, agar senantiasa bersikap sopan dan tidak bercanda atau bersenda gurau dihadapan mereka.

Akhlak anak terhadap orang tua salah satunya dengan berbakti dan berbuat baik. berbakti kepada orang tua dalam bahasa Arab disebut 
birrul walidain, ia terdiri dari kata birr (berbakti, kebajikan) dan alwalidain (dua orang tua). Dengan demikian, secara harfiyah kata birrul walidain berarti berbakti atau berbuat kebajikan kepada kedua orang tua.

Al birr adalah kata yang menyetukan seluruh kebaikan 'Aqqal wala abahu (anak telah durhaka terhadap ayahnya) bila anak meyakini, mendurhakai, dan membangkan kepadanya. Berbakti kepada ibu bapak hukumnya wajib dan durhaka kepada keduanya hukumnya haram. Tidak ada yang mengingkari keutamaan orang tua selain orang tercela (Ibrahim 2008: 63).

c. Akhlak Kepada Orang Lain

Dalam surat Luqman telah menjelaskan tentang, dan janganlah kamu memalingkan mukamu dari anusia (karena sombong) dan janganlah kamu berjalan di muka bumi dengan angkuh, sesungguhnya Allah tidak menyukai orang-orang yang sombong lagi membanggakan diri (QS. Luqman [31]: 18).

d. Akhlak Terhadap Diri Sendiri

Akhlak terhadap diri sendiri mengandung arti bagaimana memperlakukan diri sendiri, sebagai amanah dari Allah. Karena pada dasarnya semua yang di miliki oleh manusia berupa panca indera atau jasmani maupun rohani, harus diperlakukan dengan baik, adil dan sesuai dengan kemampuan. Seperti contoh diri kita memiliki mata, maka akhlak kita bagaimana menggunakan mata, dan memperlakukan mata secara propesional, kalu tidak maka diri sendiri yang menaggung akibatnya. (Warasto 2018: 69).

Penelitian yang dilakukan oleh Nidawati dengan judul "Strategi dan Arahan Akhlak Anak di Jenjang Pendidikan Dasar" berdasarkan hasil penelitian dalam pembelajaran pendidikan Islam haruslah di mulai sejak usia dini yaitu pada jenjang dasar. Pembelajaran sejak usia dini lebih efektif dan akan memiliki banyak hal positif karena arah atau tujuan dalam pendidikan Islam pada jenjang dasar.

Penelitian yang dilakukan oleh Amin Zamroni dengan judul "Strategi Pendidikan Akhlak Pada Anak" berdasarkan hasil penelitian dapat disimpulkan, setiap orang tua maupun guru yang akan mendidik anak di rumah maupun di sekolah harus mempunyai strategi, agar nantinya bisa mendidik anak dengan baik dan menjadi anak yang shalih-shalihah. Strategi pendidikan akhlak di antaranya terbagi menjdi dua yaitu pendidikan langsung dan pendidikan tidak langsung. Pendidikan langsung diantaranya adalah keteladanan, anjuran, latihan. Pendidikan tidak langsung diantranya adalah larangan, hukuman, hadia dan pengawasan.

Penelitian yang dilakukan oleh Sesi dengan judul "Strategi Guru Pendidikan Agama Islam dalam Pembinaan Akhlakul Karimah Murid Kelas V di SD Negeri I Perigi Kecamatan Pangkalanlampa Kabupaten Ogan Komering Ilir" berdasarkan hasil penelitian bahwa strategi guru PAI sangatlah penting dalam pembinaan akhlak murid, karena akhlak tidak cukup hanya dipelajari, tanpa ada strategi untuk membentuk pribadi yang berakhlak.

Berdasarkan penelitian relevan di atas dapat disimpulkan bahwa dalam pembelajaran dikelas guru harus menyiapkan strategi yang akan di pakai dalam mengajar hal ini agar pembelajaran berjalan dengan baik, apa 
lagi dalam mengembangkan akhlak pada anak usia dini. Maka strategi

C. Simpulan

pembelajaran sangat penting digunakan.

Pendidikan akhlak pada anak usia dini sangat penting untuk di terapkan agar anak memiliki bekal untuk hidup selanjutnya, dan memiliki tingkalaku yang baik, di mana anak bisa menghargai sesama manusia, baik itu yang lebih tua atau sesama teman sebayanya, hal ini dikarenakan pada usia tersebut anak masih suci dan bersih belum terkontaminasi dengan berbagai perangai buruk. Oleh karena itu seorang pendidik harus mampu memilih strategi yang baik dalam mengembangkan akhlak anak di antaranya dengan menggunakan strategi pendidikan langsung dan pendidikan tidak langsung. Pendidikan langsung diantaranya keteladanan, anjuran, dan latihan. Serta pendidikan tidak langsung diantaranya adalah, larangan, hukuman, hadia, dan pengawasan

\section{DAFTAR PUSTAKA}

Affan Zaim Muhammad. 2004. Perang Guru Pendidikan Agama Islam Dalam Pembinaan Akhlak siswa Di SMK Islami 1 Blitar.

Asmaran, As. Pengantar Studi Akhlak, Jakarta: Raja Grafindo Persada, 2002. Arief, Armai. 2002. Pengantar Ilmu dan Metodologi Pendidikan Islam. Jakarta: Ciputar Press.

Bastoni Hasan. 2017. Pendidikan Krakter Dalam Pembentukan Akhlak Anak Pra Sekolah, STAIN kudus, Jawa Tengah, Indonesia.

Gulo, 2002. Strategi Belajar Mengajar. Jakarta: PT Grasindo.

Habibah Syarifah. 2015. Akhlak Dan Etika Dalam Islam. Jurnal pesona Dasar. Vol. I, No 4

Herawati. 2017. Pendidikan Akhlak Bagi Anak Usia Dini. Vol .III. No.2 Juli-Desember 2017

Hibasa S. Rahman. 2002. Konsep Dasar Pendidikan Anak Usia Dini. Yogyakarta PGTKI Press.

Ibrahim. 2008. Wisdom Of Luqman El-Hakim:12 Cara Membentengi Kerusakan Anak. Penerjemahan: Umar Mujtahid. Judul Asli: Washaya Luqman. Solo: Aqwam.

Ibn Jamaah, Etika Akademis Dalam Islam, 82

Intani Mila. 2017. Peran Guru Pendidikan Agama Islam dalam Membentuk Akhlakul Karimah Pada Peserta Didik di SMK 1 Bulukerto Kabupaten Wonogiri Tahun Pelajaran 2017/2018. Skripsi, IAIN Surakarta.

Junaedi Muhammad. 2018. Strategi Guru Pai Terhadap pembentukan Akhlak Peserta Didik SDN 216 Dualimpoe Kecamatan Maniangpajo Kabupaten Wajo

Dewantara Hadjar Ki. 2003. Ki Hadjar Dewantara Bagian Pertama: Pendidikan. Rev. ed. Yogyakarta: UST Press

Muslich, Mansur. 2011. Pendidikan Krakter Menjawab tantangan Krisis Multidimensional. Bumi Aksara, Jakarta.

Mukmin Sa'aduddin Abdul. 2016. Meneladani Akhlak Nabi (Membangun Kepribadian Muslim), Bandung: PT: Remaja Rosda Karya.

Mulizar. 2017. Upaya Guru Pendidikan Agama Islam dalam Meningkatkan Akhlakul Karimah Siswa di SMK Muhammadiyah Kartasure Tahun Pelajaran 2016/2017. Skripsi, Universitas Muhammadiyah Surakarta.

Nurmadiah. 2016. Media Pendidikan. Jurnal Al-Afkar. Vol. V No. 1 April 2016. 
Nata Abuddin. 2003. Akhlak Tasawuf. Jakarta: Raja Grafindo.

Nashih, Ulwan Abdullah. 2003. Pendidikan Anak Dalam Islam. Jakarta: Pustaka Amami.Cet 3.

Nurmaidah. 2015. Strategi Pembelajaran Anak Usia Dini. Jurnal Al-Afkar.

Vol. III. No 1, April 2015.

Rauhun Siti. 2017. Penerapan Metode Cerita dan Nasehat Dalam Meningkatkan Hasil Belajar Siswa Pada Mata Pelajaran Pendidikan Agama Islam Di Kelas IV SDN 3 Bayumulek tahun pelajaran 2016/2017.

Sadirman, 2006. Interaksi dan Faktor Faktor yang Mempengaruhinya. Jakarta: PT. Grafindo Persada.

Wena, Made. 2009. Strategi Pembelajaran Inovatif Kontemporer. Jakarta: Bumi Aksara

Wina Sanjaya. 2010. Kurikulum dan Pembelajaran, Teori dan Praktek Pengembangan Kurikulum KTSP. Jakarta: Kencana.

Warasto Nugroho hestu. 2018. Pembentukan Akhlak Siswa. Jurnal Mandiri. Vol 2, No, 1 Juni 2018

Zamroni Amin . 2017. Strategi Pendidikan Akhlak Pada Anak.. Semarang: Universitas Islam Sultan Agung. Vol. 12. No. 2.

Zuhairini Dkk. 2004. Metode Khusus Pendidikan Agama. Jakarta; Usaha Nasional. 